\title{
Knowledge Sharing Attitudes of Library and Information Science Professionals in Nigeria
}

\author{
Oluwatoyin O. Obinyan, ${ }^{1 *} \quad$ Charity O. Adetona ${ }^{1} \quad$ John M. Adeniyi ${ }^{2}$ \\ 1.Ambrose Alli University, Ekpoma \\ 2.Kogi State College of Education, Ankpa
}

\begin{abstract}
Knowledge sharing in an organization nowadays has been a strong force toward attaining organizational goals. Library and Information Science (LIS) professionals are at the forefront of information gathering and dissemination, and at such, knowledge sharing among such professionals needs to be investigated. The study examined the attitudes of LIS professionals in Nigeria toward knowledge sharing; and they comprised the population of the study in this research. The responses were collated through online survey using Google forms; the link was posted on Nigerian Library Association online platform and WhatsApp groups of all the library professionals in Nigeria, given a timeframe of two weeks for data collection. Descriptive statistics was employed for data analysis. Ninety-four responses were recorded within a space of two weeks. The results revealed that the attitudes of LIS professionals to knowledge sharing with a grand mean score of 4.5, which indicated positive attitudes. The avenue for knowledge sharing varies significantly from Conferences, Seminars, Face-to-face with social media platforms. Also, years of work experience was found to have significant influence on intrinsic motivational factors to sustain knowledge sharing attitudes of the professionals in library and information science specialty in Nigeria. The second hypothesis was also rejected for the acceptance of the alternative hypothesis that states that extrinsic motivation has significant influence on knowledge sharing attitudes of library and information science professionals in Nigeria. Therefore, the study recommends, among, others that a mentoring programme be established for peer-to-peer and promotion of knowledge sharing should further be strengthened.

Keywords: Extrinsic motivation, Intrinsic motivational factors, Knowledge sharing attitudes, Knowledge sharing, Library and Information Science Professionals, Nigeria.
\end{abstract}

DOI: $10.7176 / \mathrm{IKM} / 11-1-01$

Publication date: January $31^{\text {st }} 2021$

\section{Introduction}

Knowledge is neither information nor data; but "unique insights, intuition, and inspiration generated by continuous learning and thinking gained through practice and cannot exist independently and have a more excellent value than information." To further expand the meaning of knowledge beyond the dictionary meaning, and not to be trapped in a narrow confine of a printed or electronic media, Davenport and Prusak (1998) defined knowledge as "a fluid mix of framed experiences, values, contextual information, and expert insight that provide a framework of evaluating and incorporating new experiences and information. It originates and is applied in the minds of knowers."

In organizations, it is often embedded in documents or repositories and organizational routines, practices, and norms. When knowledge has been generated, it has to be managed. According to Ardichvili, Maurer, Lin, Wentling, and Stuedemann (2006), "knowledge management is not as simple as it may sound. It is a hybrid socio-technical system that combines various knowledge generation, storage, representation, and sharing."

Knowledge management in libraries, therefore, refers to "effectively identifying, acquiring, developing, revolving, using, storing, and sharing knowledge to create an approach to transforming and sharing tacit and explicit knowledge and to raise emergency and innovative capabilities by utilizing the wisdom of the team" (Daniel, 2015). "Knowledge management is a managerial activity which develops, transfer, transmit, stores and applies knowledge, as well as providing the members of the organization with real information to react to and make the right decisions, to attain the organization's goals" (Kanagasabapathy, Radhakrishnan, \& Balasubramanian, 2006). The underlying philosophy of knowledge management is to enhance knowledge sharing and accessibility.

Knowledge sharing as a process involves synchronization of learning activities. Besides, it is the process where individuals mutually exchange their knowledge and jointly create new experience(s).

"Knowledge sharing helps workers solve problems, learn new things, and increase understanding.

Workers can learn from each other and benefit from new knowledge and development by one another. Workers who can share knowledge are more productive and more likely to survive in their jobs than workers that do not. Librarians are helped through the knowledge shared by other librarians who have experienced practice; this enhances worker's efficiency in the library organization" (Yang, 2004).

Knowledge sharing is a process that consists of bringing knowledge and getting knowledge. Those with limited knowledge benefit from the advantage of knowledge sharing (DenHooff \& DeRidder, 2007; \& Yang, 2004). To enhance common understanding among librarians, they have to share knowledge, experiences, thoughts, and 
beliefs. To this extent therefore, Peariasamy (2009) stated that "the most significant result of using knowledgesharing practices is to improve workers' skills and knowledge", in addition to increasing workers' efficiency and productivity. Library and Information professionals should tend towards knowledge sharing to make the Library more proficient than ever before. Now the characteristics and demands of users are becoming more diverse. Bock, $\mathrm{Kim}$, and Lee (2005) conducted a study that "investigated the positive effect of attitudes towards knowledge sharing on individuals' intentions to share knowledge" and the outcome revealed positive intention.

According to Shin, Ramayah, and Jahani (2008), "absence of positive attitudes towards knowledge sharing can lead to selfishness, knowledge restraints and conflicts" and can retard the library's effectiveness as a serviceoriented organization. In an attempt to emphasize the importance of knowledge sharing, Oosterlinck (2004) avers that "knowledge sharing helps students receive additional feedback and improves their further research initiatives."

The study is aimed at investigating knowledge sharing attitudes of Library and Information Science professionals in Nigeria. The following objectives were drawn for the study:

- $\quad$ To find out the knowledge sharing attitudes of library and Information Science Professionals in Nigeria;

- To find out how the avenues through which knowledge was shared among Library and Information Science Professionals in Nigeria.

- To determine the contributions of years of experience and intrinsic motivational factors to knowledge sharing among Library and Information Science professionals in Nigeria;

- To examine the influence of extrinsic motivational factors on knowledge sharing attitudes of Library and Information Science Professionals in Nigeria.

\section{Research questions}

1. What are the knowledge sharing attitudes of LIS professionals in Nigeria?

2. What are the avenues through which LIS professionals in Nigeria share knowledge?

\section{Hypothesis}

1. $\mathrm{H}_{\mathrm{o}}$ : Years of work experience has no significant influence on intrinsic motivational factors to sustain knowledge sharing attitudes of LIS professionals in Nigeria.

$\mathrm{H}_{\mathrm{I}}$ : Years of work experience has significant influence on intrinsic motivational factors to sustain knowledge sharing attitudes of LIS professionals in Nigeria.

2. $\mathrm{H}_{\mathrm{o}}$ : Extrinsic motivation has no significant influence on knowledge sharing attitudes of LIS professionals in Nigeria.

$\mathrm{H}_{\mathrm{I}}$ : Extrinsic motivation has significant influence on knowledge sharing attitudes of LIS professionals in Nigeria.

\section{LITERATURE REVIEW}

According to Yang (2004), "to achieve knowledge effectiveness, individual knowledge needs to be shared, and unless individual knowledge is shared with others, the knowledge is likely to have limited impact on effectiveness." To ensure a good flow of information to mitigate uncertainty, librarians must share knowledge; the absence will lead to information hoarding.

"Knowledge sharing is defined as the voluntary and social process of transferring, absorbing, and reusing existing knowledge to serve an organizational end" (Harder, 2008). This definition emphasizes the voluntary and social nature of knowledge sharing, where individual motivation becomes the main factor in explaining knowledge sharing behaviour. This does not mean that managers cannot influence knowledge sharing. Indeed, managers can influence motivation to share knowledge in numerous ways, not the least via reward structures and management styles. However, the factors that motivate knowledge sharing are likely to differ from those that inspire more simple and measurable tasks (Osterloh \& Frey, 2000). According to Van den Hoff and de Ridder (2006), knowledge sharing is "the process of exchanging knowledge and jointly creating new knowledge." Kim and Lee (2006) also describe knowledge sharing as employees' ability to share their work-related experience, expertise, and know-how with other employees through informal or formal methods within an organization.

To produce both products and services innovation in the libraries, Anna and Puspitasari (2013) posit that some libraries already have a more advanced vision by applying knowledge sharing with various purposes, significantly enhancing knowledge creation among staff. Daniel's (2005) study revealed that librarians shared knowledge in university libraries as they saw the need to work together to improve their performances and extend the understanding of libraries beyond the provision of services to knowledge creation and discovery for the benefit of community of users. Onifade (2015) affirmed that knowledge sharing among librarians is vital as part of the knowledge management process. Intrinsic or extrinsic factors of motivation could influence the motivation toward sharing knowledge in an organization.

Deci, as far back as 1975 sees "intrinsic motivation as engaging in an activity for its own sake, out of interest, or for the pleasure and satisfaction derived from the experiences." Research works recognize the role of intrinsic 
motivators in explaining human behaviours in several domains. Osterloh and Frey (2000), in their contribution, consider "reputation as a strong motivation to share knowledge" while Lin (2007) indicates that "enjoyment in helping others gingers knowledge sharing." According to Szulanski (1996), the source's intrinsic motivation is the most crucial factor in knowledge sharing. Therefore, it has the aptitude to transmit the message and the desire to share it. This intrinsic motivation is especially essential for the transfer of tacit knowledge. The study proposes enjoyment in helping others, obtaining achievement and success, and reputation as three conditions that form faculties' intrinsic motivation for knowledge sharing. According to Sutton (2009), to encourage staff to engage in knowledge sharing, they need to be given inherent rewards such as the opportunity to go for conferences, training, or recognition.

The sharing of knowledge that involves the provision of tasks and know-how to help others do occur through many avenues such as face-to-face, capturing, networking with other experts in the professions (Cummings, 2004). The options available for knowledge transfer/sharing include networks, electronic mails, and the internet to meet users' information needs in the $21^{\text {st }}$ century. Fayose and Nwalo (2000) wrote that university libraries are interested in using technology to network operations such as administration, cataloguing, interlibrary loan, and international bibliographic project. If properly utilized, it will help the growth and development of libraries in different directions. It will allow easy integration of various activities, facilitates cooperation, avoids duplication of efforts within the library and among libraries in a network, eliminates some uninteresting and repetitive work, and provides a marketing opportunity for its services. Twenty years down the line, there has been a spike and increase deployment and use of technologies in virtually every facet of library operations including knowledge sharing. According to Anna and Puspitasari (2013), libraries support knowledge sharing with computers and internet networks. Nazim (2016) study affirmed that library professionals most use information technology-based tools for sharing of knowledge with their colleague.

\section{Methodology}

This study adopted a correlational type survey research design to investigate LIS professionals' knowledge sharing attitudes in Nigeria. The study population was made up of all the LIS professionals in Nigeria. A questionnaire was used as the instrument for data collection. The questionnaire was made up of five parts; the first part addressed the issue characteristics of the respondents; second part listed four questions to assess respondents' perceptions of knowledge sharing attitudes of LIS professionals, the third part concerns itself with factors of intrinsic motivation, the fourth part on extrinsic motivational factors, and the fifth section on knowledge sharing avenue. A five-likethtype scale point scale ranging from $1=$ Strongly Disagree to $5=$ Strongly Agree was used. Items in the questionnaire were adapted from the work of Garoufallou, Siatri, Asderi and Balatsoukas (2010). The responses were collated through an online survey using Google forms. The link was posted to the Nigerian Library Association (NLA) online platforms and WhatsApp groups of all the library professionals in Nigeria. A timeframe of three weeks was given to complete the survey, after which the online survey was closed from accepting responses. Ninety-four responses were recorded within a space of three weeks. The data collected were coded in a spreadsheet and analyzed using Statistical packages for Social Science (SPSS, Version 23). Descriptive statistics of frequency count, percentages, and mean were used to analyses research questions, while one-way ANOVA was used to test the two hypotheses postulated in the study.

\section{Findings}

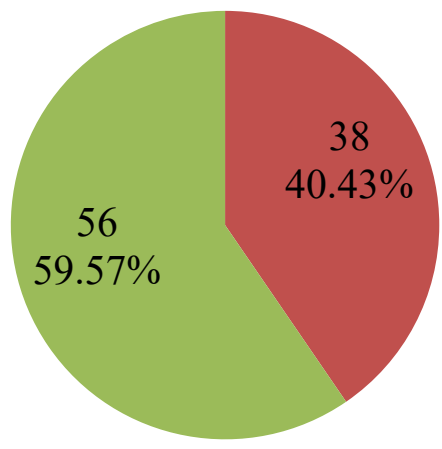

- Gender

- Male

Female

Figure 1: Gender of the respondents 
As shown in Figure 1, most of the respondents, 56 (59.57\%), were females, while 38 (40.34\%) were males. This implies that females were more in the profession of Library and Information Science than males in Nigeria.

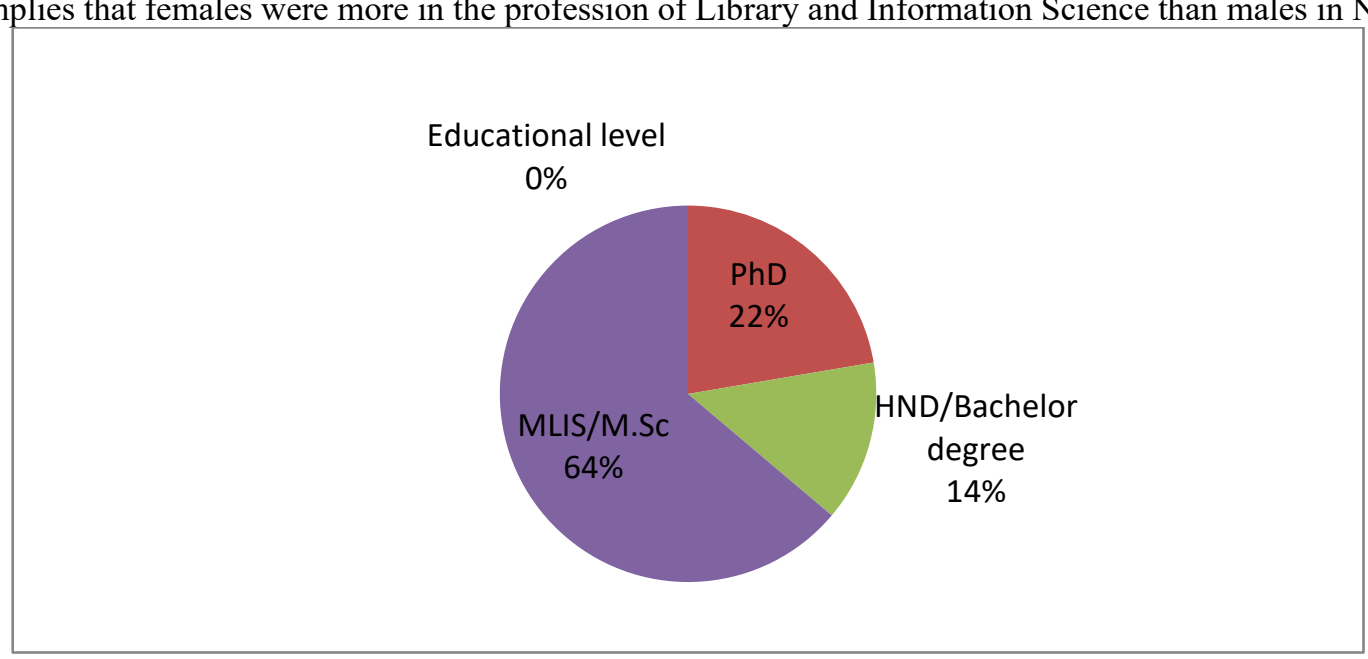

Figure 2: Educational Level of the Respondents

Figure 2 revealed that (64\%) of the respondents possessed MLIS/M.Sc degrees, 21(22\%) were PhD degree holders, while $13(14 \%)$ are in the categories of holders of HND/Bachelor degree.

\section{Type of Library}

61

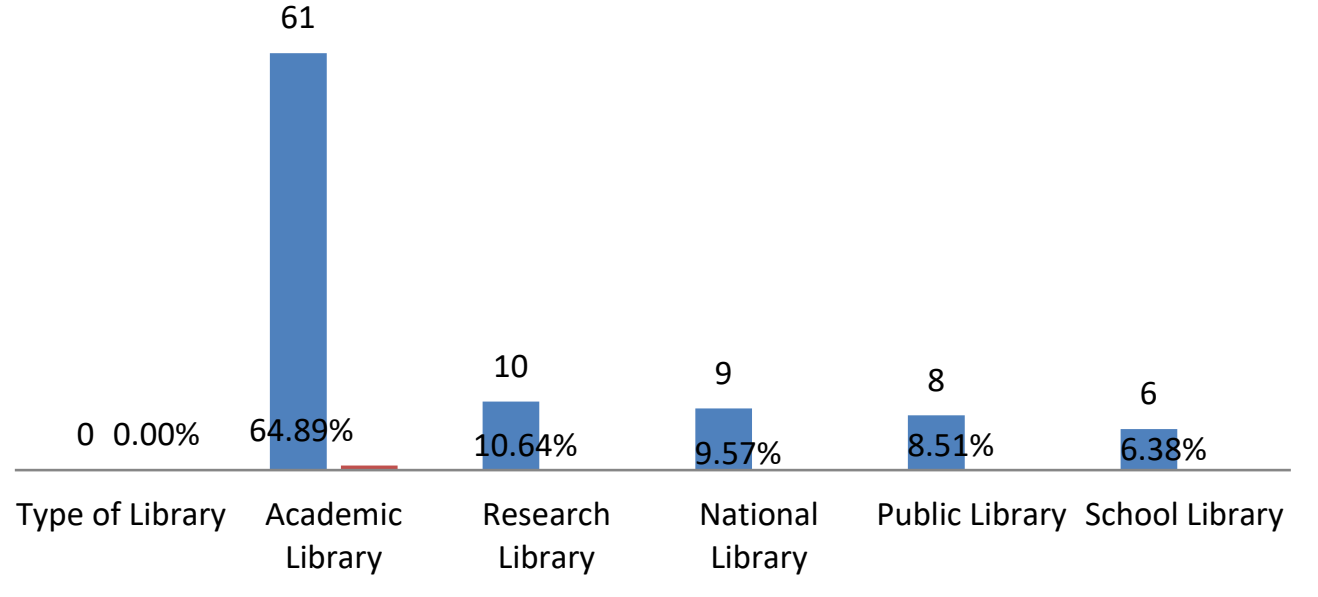

Figure 3: Type of Libraries

Figure 3 revealed the type of libraries in Nigeria. The majority of the respondents, 61(64.89\%), were from academic library, 10(10.64\%) from Research library, 9(9.57\%) were from the national library, 8(8.51\%) respondents were from Public library, while 6(6.38\%) respondents being the least were from the school library. 


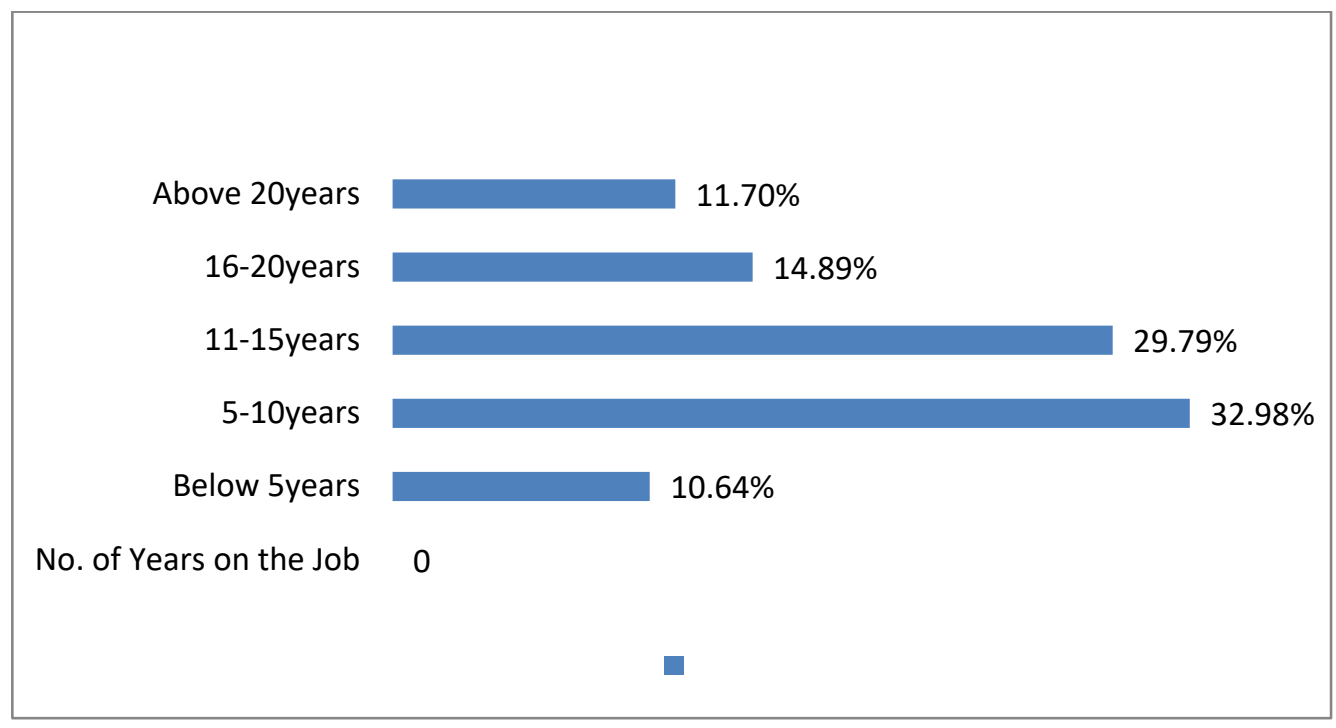

Figure 4: Years of Work Experience of the Respondents

Figure 4: shows the years of work experience of the respondents on the job as library workers. From the distribution pattern, 31(32.98\%) respondents had 5-10 years of work experience. This is closely followed by $28(29.79 \%)$ respondents with between 11-15 years of work experience. Among the responding LIS professionals, only $11.70 \%$ and $10.64 \%$ have had above 20 years and below five years of work experience on the job respectively. It is clear from the results that most of the respondents had between 5-10 years of work experience.

\section{Findings from Research Questions}

Decision rule: if the mean is $<3.0=$ low level, 3.0- 3.9 = Moderate/Fairly high level, $>$ 4.0 Very High level

Research Question 1: What are the knowledge sharing attitudes of LIS professionals in Nigeria?

Table 1: Knowledge Sharing Attitudes of LIS Professionals in Nigeria

\begin{tabular}{|c|c|c|c|c|c|c|c|c|c|c|c|c|}
\hline $\begin{array}{l}\text { Knowledge Sharing } \\
\text { Attitudes }\end{array}$ & \multicolumn{2}{|c|}{$\begin{array}{l}\text { Strongly } \\
\text { Agree } \\
\mathrm{F} \quad(\%)\end{array}$} & \multicolumn{2}{|c|}{$\begin{array}{l}\text { Agree } \\
\mathrm{F} \quad(\%)\end{array}$} & \multicolumn{2}{|c|}{$\begin{array}{l}\text { Neutral } \\
\mathrm{F} \quad(\%)\end{array}$} & \multicolumn{2}{|c|}{ Disagree } & \multicolumn{2}{|c|}{$\begin{array}{l}\text { Strongly } \\
\text { Disagree }\end{array}$} & \multirow{2}{*}{$\begin{array}{l}\text { Mean } \\
4.6\end{array}$} & \multirow{2}{*}{$\begin{array}{l}\text { Decision } \\
\text { VHL }\end{array}$} \\
\hline $\begin{array}{l}\text { When I have knowledge } \\
\text { that might be relevant for } \\
\text { others in the library, I do } \\
\text { what I can to make it } \\
\text { available to them. }\end{array}$ & 59 & 62.8 & 31 & 33.0 & 4 & 4.3 & - & - & - & - & & \\
\hline $\begin{array}{l}\text { When a colleague asks } \\
\text { me for help or assistance, } \\
\text { I share what knowledge I } \\
\text { may have on the subject }\end{array}$ & 60 & 63.8 & 31 & 33.0 & 3 & 3.2 & - & - & - & - & 4.6 & VHL \\
\hline $\begin{array}{l}\text { I stay updated by } \\
\text { exploring } \\
\text { information I can find on } \\
\text { the different knowledge } \\
\text { systems and databases }\end{array}$ & 44 & 46.8 & 48 & 51.1 & 1 & 1.1 & - & - & 1 & 1.1 & 4.4 & VHL \\
\hline $\begin{array}{l}\text { When I encounter a } \\
\text { work-related problem, I } \\
\text { seek knowledge and help } \\
\text { from my colleagues }\end{array}$ & 41 & 43.6 & 47 & 50.0 & 6 & 6.4 & - & - & - & - & 4.4 & VHL \\
\hline Grand Mean & & & & & & & & & & & 4.5 & VHL \\
\hline
\end{tabular}

Table 1: shows the grand mean score of 4.5 of knowledge sharing attitudes of the LIS professionals in Nigeria. The implication of this is that knowledge sharing attitudes of LIS professionals is to a very high level whenever the need to share knowledge arises. 
Research Question 2: What are the avenues through which LIS professionals in Nigeria share knowledge?

\section{Knowledge Sharing Avenue}

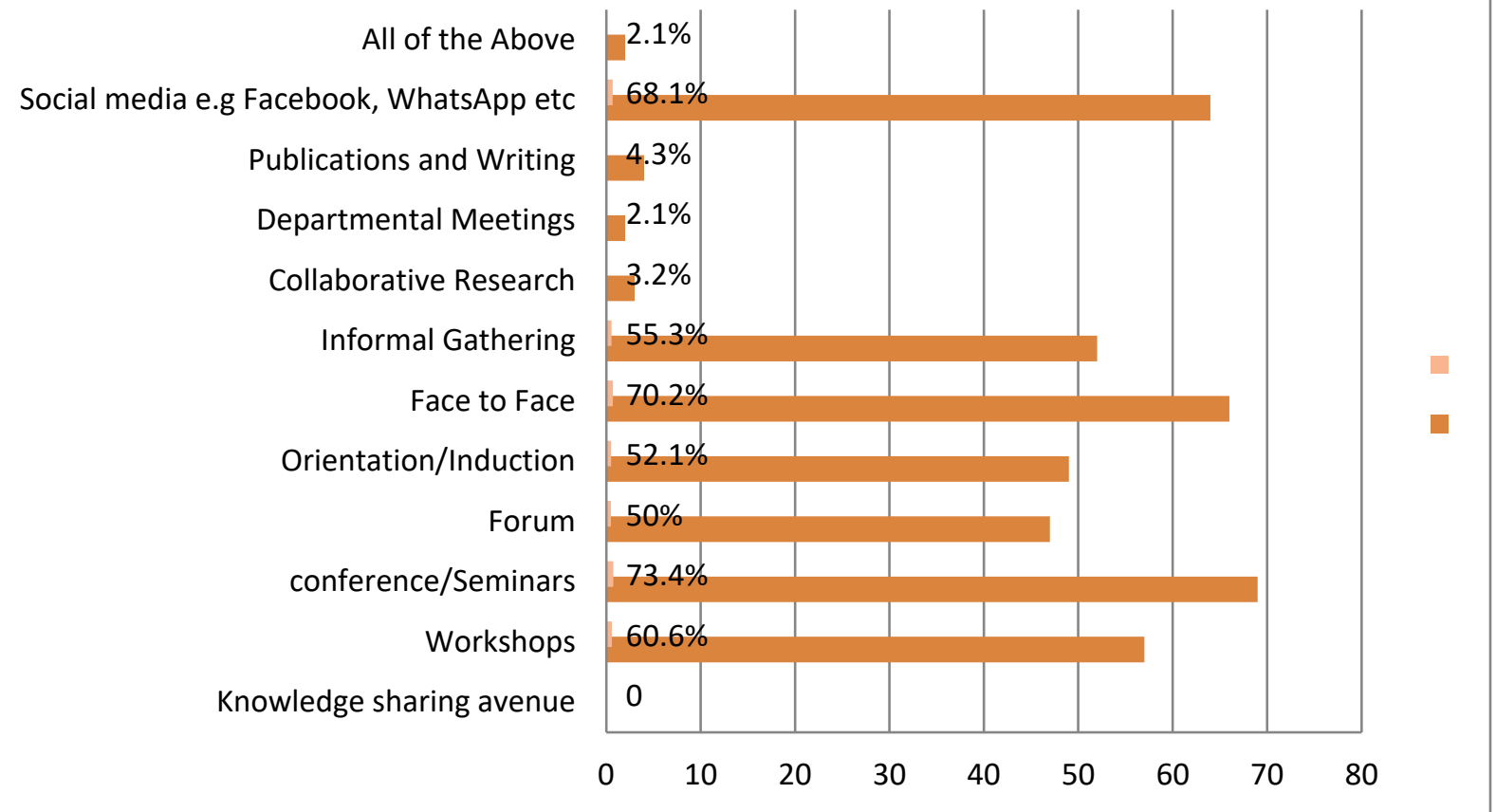

Figure 6: Knowledge Sharing Avenues

Figure 6 provides answers to the research question on the avenue through which LIS professionals shared knowledge. For instance, 69(73.4\%) of the respondents used conferences/Seminars, Face-to-face 66(70.2\%), social Media avenue 64 (68.1\%), Workshops 64(60.6\%). Fewer persons used avenues such as Collaborative research 3(3.2\%) and Departmental Meetings 2(2.1\%).

Test of Hypotheses

Hypothesis 1: Years of Work Experience has no significant influence on intrinsic motivation to share knowledge among LIS professionals in Nigeria.

\begin{tabular}{|l|l|l|l|l|l|}
\hline Model & Sum of Squares & Df & Mean Square & F & Sig. \\
\hline Regression & .009 & 1 & .009 & .094 & $.760^{\mathrm{b}}$ \\
Residual & 8.927 & 92 & .097 & & \\
Total & 8.936 & 93 & & & \\
\hline
\end{tabular}

a. Dependent Variable: Factors of intrinsic motivation

b. Predictors: (Constant), Years of work experience

R Square $=.001$

Adjusted R Square $=-010$

The results contained in Table 2 show the influence of years of work experience on intrinsic motivation for knowledge sharing among LIS professionals. The ANOVA summary shows $\mathrm{F}=.094$, which was found to be significant at .05 level of probability. Based on this outcome, the null hypothesis was rejected for the acceptance of the alternative hypothesis. The implication of this is that years of work experience and Intrinsic motivational factors have a significant influence on the knowledge sharing attitudes of LIS professionals in Nigeria.

Hypothesis 2: $\mathrm{H}_{0}$ : Extrinsic motivation has no significant influence on knowledge sharing attitudes of LIS professionals in Nigeria.

\begin{tabular}{|l|l|l|l|l|l|l|}
\hline Source of Variation & Sum of Squares & Df & Mean Square & F & Sig. & Remark \\
\hline Due to Regression & .223 & 1 & .223 & 7.635 & $.007^{\mathrm{b}}$ & Significant @ 0.05 \\
Due to Residual & 2.682 & 92 & .029 & & & \\
Total & 2.904 & 93 & & & & \\
\hline
\end{tabular}

Dependent Variable: Knowledge sharing attitudes

b. Predictors: (Constant), Extrinsic motivation

R Square $=.077$

Adjusted R Square $=.067$

The results contained in Table 3 show the significant influence of extrinsic motivation on knowledge sharing 
attitudes among LIS professionals. The ANOVA summary shows $\mathrm{F}=7.635$ that was found to be significant at .05 level of probability. Consequently, the null hypothesis is rejected for the acceptance of the alternative hypothesis. The implication of this is that extrinsic motivation has significant influence on the knowledge sharing attitudes of LIS professionals in Nigeria.

\section{Discussion of findings}

The result on the level of knowledge sharing attitude of LIS professionals revealed that all the respondents shared knowledge among their colleagues, which indicated a positive attitude toward knowledge sharing with the grand mean score of 4.5. This is in line with Ogunmodede and Popoola (2019) study that reported a high rate of knowledge sharing among librarians in federal universities in Nigeria and a positive attitude toward knowledge sharing.

The study revealed the various avenues by which LIS professionals share knowledge. It is revealed that most of the respondents $(73.4 \%)$ used Conference/Seminars avenue for knowledge sharing. This finding is supported by Okonedo and Popoola (2012) work that reported in their results that LIP share knowledge through Seminars and Workshops. The study also revealed that $70.2 \%$ of the respondents use Face-to-face, $68.1 \%$ use Social Media platforms. These findings are in line with the study of Nassuora (2011), and Ilako and Akeriwe, (2016).. In contrast, avenue such as Collaborative research 3(3.2\%) and Departmental Meetings 2(2.1\%) was used by fewer persons in knowledge sharing.

The finding from the hypotheses tested revealed that years of experience and intrinsic motivational factors have significant influence on the knowledge sharing attitudes of LIS professionals in Nigeria.

The second hypothesis also shows that extrinsic motivation has significant effects on knowledge sharing attitude of LIS professionals in Nigeria. This implied that external motivational factors have greatly insignificant on knowledge sharing attitudes of LIS professionals have greatly insignificant external motivational factors on knowledge sharing. This can be corroborated with the finding of Ilako and Ikoja-Odongo (2011) that revealed that librarians in Makerere university shared their knowledge with a colleague in the form of experience, insight as well as in codified form (tacit and explicit).

\section{Conclusion and Recommendations}

Knowledge sharing is seen as one of the factors that contributed significantly to organizations growth and development. The findings have shown that knowledge sharing is an integral part of library and information science professionals in Nigeria. The attitudes toward sharing knowledge among peers are significantly high. The most common avenue for knowledge sharing is conferences and workshops and years of experience is seen to substantially influence knowledge sharing attitude of the library and information science professionals in Nigeria. It can be deduced that LIS professionals have a high level of attitude toward knowledge sharing; this could be as a result of intrinsic and extrinsic motivational factors. The library and information centres and schools in Nigeria should therefore create a climate which prompts knowledge sharing.

The study, therefore, recommends that:

1. The various libraries and schools should further encourage an increase in Knowledge sharing among their staff by providing supports in term of commendation letters, promotions etc.

2. Knowledge sharing should be encouraged during meetings.

3. Collaborative research that aid knowledge sharing should be encouraged among practitioners.

4. Mentoring system as an avenue for knowledge sharing is highly recommended. This will facilitate knowledge distribution and sharing most, especially between senior officers and junior officers.

5. Library and information science association should promote knowledge sharing among professional in Nigeria to meet up with advancements in technological development in library science education.

\section{References}

Anna, N.E. \& Puspitasari, N. (2013). Knowledge sharing in libraries: A case study of knowledge sharing strategies in Indonesian University Libraries. IFLA WLIC. 1-11

Ardichvili, A., Maurer, M., Lin, W., Wentling, T. \& Stuedemann, R. (2006). Cultural influences on knowledge sharing through online communities of practice, Journal of Knowledge Management, 10(1), 94-107.

Bock, G. W. A., Kim, Y. G. \& Lee, J. N. (2005). Behavioral intention formation in knowledge sharing: examining the roles of extrinsic motivators, social-psychological forces and organizational climate. MIS Quarterly. 29(1), 87-111.

Cummings, J. N. (2004). Work groups, structural diversity and knowledge sharing in a global organization. Management Science, 50(3), 352-364. Doi: 10.1287/mnsc.1030.0134.

Daniel, A. (2015). Knowledge sharing among librarians in university libraries in Nigeria. Information and Knowledge Management. 5(2), 31-35

Davenport, T. H. \& Prusak, L. (1998). Working knowledge: How organizations manage what they know. Harvard 
Business School Press. Boston. MA.

Deci, E. L. (1975). Intrinsic Motivation. New York: Plenum press

DenHooff, B. \& DeRidder, J. A. (2007). Knowledge sharing in context: the influence of organizational commitment, communication climate and civic use knowledge sharing Journal of Knowledge Management $8(6), 117-130$

Etim. F. C. (2010). Library and information science perspective: a compendium of researches of Felicia Edu-Ewen Etim. Akwa Ibom: Nigeria Library Association

Fayose, P. \& Nwalo, K. N. (2000). Information technology in library and information science education in Nigeria. Papers presented at the $10^{\text {th }}$ Biennial conference of the NLA and NALISE.

Garofallou, E. Siatri, R. Asderi, S. \& Balatsoukas, P. (2010). Sharing knowledge on workplace: What factors motivate librarians to share their knowledge. Qualitative and Quantitative Methods in Libraries: Theory and Applications, 70-75.

Harder, M. (2008). How do rewards and management styles Influence the motivation to share knowledge?

Ilako, C. \& Akeriwe, M. L. (2016). The use of Web 2.0 applications for knowledge sharing among academic libraries in Uganda and Ghana. Paper presented at IFLA WLIC 2016 - Columbus, OH. Retrieved from http://library.ifla.org/id/eprint/1393.

Ilako, C. \& Ikoja-Odongo, R. (2011). Creativity and innovations in Ugandan libraries: case of Makerere University library. IFLA 2011 Puerto rice 13-18 August. Retrieved from http://conference.ifla.org/ifla77.

Kamal, S. N. M., Osman, S., Ali, M. Z., Noor, J. M. M., Anuar, M. A. W. \& Othman, R. (2015). Mechanisms of Knowledge Sharing among undergraduate students in UiTM Johor. Science Direcct. Procedia Economics and Finance 31, 903-908.

Kanagasabapathy, K. A. Radhakrishnan, R. \& Balasubramanian, S. (2006). Empirical investigation of critical success factor and knowledge management structure for success implementation of knowledge system: A case study in process industry. Available at: http://hosteddocs.ittoolbox.com/KKRR41106.pdf

Kim, S. Lee, H. (2006). The impact of organizational context and information technology on employee knowledge sharing capabilities. Public Administration Review, 66(30). Doi.org/10.1111/j.1540-6210.2006.00595.x.

Lin, H. F. (2007). Effects of extrinsic and intrinsic motivation on employee knowledge sharing intentions. Journal of Information Science 33(2), 135-149.

Lundvall, B. (2006). Interactive learning, social capital, and economic performance. In BianKahin and Dominique Foray (ed). Advancing Knowledge and the Knowledge Economy. Cambridge, Massachusetts: MIT Press. 6374

Nazim, M. (2016). Knowledge sharing attitude of library professionals: a survey. Journal of Knowledge and Communication Management, 6(2), 154. Doi: 10.5985/2277-7946.2016.00013.9.

Ogunmodede, T. \& Popoola, S. (2019). Knowledge sharing behaviour by librarians in Federal Universities in Nigeria. Journal of Balkan Libraries Union 6(1), 20-33. Retrieved from: https://dergipark.org.tr/en/pub/jblu/issue/50569/584475.

Okonedo, S. \& Popoola, S. O. (2012). Effect of self-concept, knowledge sharing and utilization

on research productivity among librarians in public universities in South-West Nigeria. Library Philosophy and Practice. Retrieved from http://digitalcommons.unl.edu/libphilprac/322.

Onifade, F. N. (2015). Knowledge sharing among librarians in federal University libraries in Nigeria. Information and Knowledge Management, 5(3), 91-97.

Oosterlinck, A. (2004). Knowledge management in Post-Secondary education: Universities.OECD working paper.

Osterloh. M. \& Frey, B. (2000). Motivation, knowledge transfer and organizational forms.

Organization Science 119(5), 538-550.

Pearisamy, T. (2009). A Study on the influence of performance reward on knowledge sharing, factors, barriers and recommendation http://www.fppsm.utm.my/files/journal/JK.07/706.PDF.

Shin, C. H., Ramayah, T. \& Jahani, S. (2008). Using theory of reasoned action to explain intention to share knowledge among academics. www.apera.nie.edu.sg/activities/.../APERA08_day3_programme.pdf

Sutton, M. (2009). Knowledge citizen's approach to knowledge sharing, rewards, and incentive. South African Journal of Information Management 8(3), a224.

Szuvanski, G. (1996). Exploring internal stickiness: impediments to the transfer of best practice within the firm. Strategic Management Journal, 17(S2), 27-43.

Yang, J. (2004). Job related knowledge sharing, comparative study. Journal of Knowledge Management 8(3), 118126. 